\title{
In the peeng
}

Welcome to the June 2010 issue of CERL News. As we prepare to head to Washington, D.C., for the 2010 ALA Annual Conference, many academic and research librarians are thinking about the future of our profession. The ACRL Research Planning and Review Committee "2010 top ten trends in academic libraries" report, which appears in this issue, is an excellent starting point for discussion. The report outlines trends that are affecting academic libraries now and in the near future, including budgets, assessment, collaboration, digitization, and new technologies.

Teaching and instructional issues are always a major part of the life of academic libraries. In this issue, David Pavelich discusses "Lighting fires in creative minds" by using special collections resources in teaching creative writing. The program is also a great example of the trend towards increased collaboration on campus.
Increasing use of technology in libraries is another major trend noted in the report. In this issue, librarians from the University of California-Merced write about their use of digital signage to promote their services and other campus activities in the library.

With summer fast approaching, many librarians are beginning to relocate for new job opportunities starting fall semester. Jennifer Nutefall recently relocated across the country for work and provides valuable advice for adjusting to a new job and community in her article "Moving for your career?" Summer often means a change in library usage patterns. Paul Metz takes a look at how these seasonal variations often result in "Two universities in one place."

Make sure to take a look at all of the other great articles and columns, including Internet Resources on "Speculative Realism" and complete 2010 ACRL election results.

-David Free, editor-in-chief dfree@ala.org

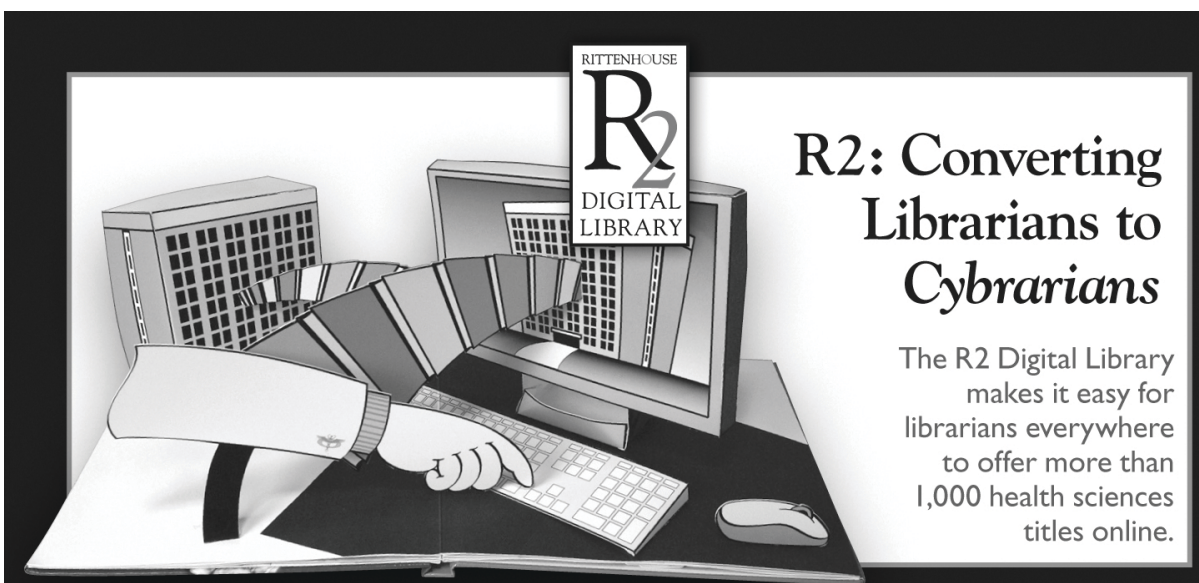

SAYE MONEY.

Avoid "all-or-nothing" prices. Add more titles immediately with the push of a button.

SAVE TIME.

Easy-to-use interface. If you can surf the web, you can use R2.

MANAGE SMARTLY.

Monitor usage statistic in real time, so you can make informed decisions.

Rittenhouse

B OOK DISTR IBUTORS
5II Feheley Dr., King of Prussia, PA 19406 • 800-345-6425 www.r2library.com * www.rittenhouse.com 